\title{
Editorial
}

\section{Good Will Hunting, Intellectual Humility, and Conversations in Quarantine}

"If we truly want to know, sometimes it means recognizing when we don't know."

Let me preface this editorial by saying that it has been a strange few weeks on top of an "unprecedented" year of both disruption and realization - which has all led to some interesting conversations and reflection recently.

A few weeks ago, my 16-year-old asked if we could watch Good Will Hunting (recommended by her AP Psych teacher). I'm a fan of classic Robin Williams movies, so we sat down to watch with my 18-year-old (who is currently applying for college with plans to study psychology and languages), and it was a very eye-opening experience. It had been a few years since I had last seen this film, but this time I was watching it from several new perspectives:

- As a mother watching her daughters' reactions and having conversations with them about it

- As the mother of a college-bound youth considering how she can navigate a path that will allow her to find a career/job where she can both contribute and be satisfied

- As a consumer of higher education (considering ROI)

- As a member of the higher education community and witness to the accelerated transformations it has undergone and continues to experience.

Discussing this film with my daughters resurfaced some of my own long-held assumptions about higher education and learning and intelligence. For instance, when I was young, there was always the assumption that I would go to college (a privilege that not everyone has). Now I question this assumption for my own children. This questioning is coupled with how COVID-19 has transformed learning (whether for the long-term or the short-term). As a mother, it is difficult to hear about the struggles that public school students (and some college students) have with learning in an online environment. Having witnessed the shift that simply took in-person teaching and attempted (however imperfectly) to translate it to an electronic environment, it is clear that teaching with technology is not a mere translation to online. It's not like taking a print text and scanning it to pdf. The methods for teaching and for learning are entirely different, and it's not the fault of the instructors or teachers. It is because trying to replicate in-person learning with technology is no easy task. The transition by so many institutions from in-person (aka "high contact") to online learning has raised some questions for me, as both a parent and a consumer (i.e., paying the bills and wanting to properly prepare my children for adulting), and are probably more pragmatic than intellectual in nature. Questions like:

- If she gets accepted to a college out of state and ends up taking classes online, what does that mean for her learning?

- Does she go out of state and isolate and take classes virtually there? If so, would she miss much of the college experience and opportunities to adult? 
Also, given that college should be, in my mind, a pathway to a career and to financial and social independence, what is at the end of her experience, given all the recent changes? How will she move from adulting to adult-ed (if any of us ever really do)?

These thoughts have also crossed over to a more work-related, academic focus:

- What does the in-person experience bring in terms of learning (and, in the buzzwords of higher education, student success?)

- Does the online experience approximate the in-person learning environment adequately?

- Are there ways that the online educational environment can employ facets that enhance learning in a way that face-to-face does not?

- And, more generally, is formal higher education providing what society and individuals need to be productive and successful?

These are questions that are tackled by researchers and authors in librarianship and in higher education - some of which are addressed by studies in College $\mathcal{E}$ Research Libraries.

My (theoretically) college-bound daughter and I had a later conversation (prompted by a piece of furniture malfunctioning last week) that started with her comment that she thought that being able to fix the broken metal bracket with "those sparky welding tools" (tack welding) would be pretty cool. This led us into a discussion about how welding was a much needed, in-demand, and at times lucrative (if potentially dangerous and physically demanding) career-and if this were something she was interested in, she could look into it. While the assumption in the house is that our children would go to college (or advanced schooling), I have often joked that the most secure careers will be things like welding and plumbing (because there is always $\mathrm{cr}^{*} \mathrm{p}$ to clean up!) or maybe podiatry since the height of the heels people wear now undoubtedly cause foot and back problems! (But maybe that's just me speaking in my sensible shoes.)

These conversations reminded me of a commentary I watched last summer from the BBC, which explored intellectual humility. It stuck with me because it is a trait I aspire (and admittedly, often fail) to practice. ${ }^{2}$

When I mentioned intellectual humility to my daughter, she said that it sounded like an oxymoron - that the term intellectual evoked a notion of arrogant knowledge which seemed the complete opposite of humility. I cannot say I disagree - when I think about the term intellectual, I am somewhat put in mind of elitism in the academy. Although, watching Good Will Hunting was a good reminder that intellect (and genius) is not tied to academia and having PhD after your name is not a requirement.

So, the more I looked at the concept of intellectual humility (and there is a fair bit written on the topic), the more I was attracted to it - and could see its application in a variety of situations.

The concept refers to the Dunning-Kruger effect, ${ }^{3}$ which is a somewhat controversial theory that indicates that those with low ability tend to overestimate their ability. This may also be considered a somewhat elitist theory - until one realizes that we all have areas where we have low ability. It demonstrates that genius can come from anywhere and does not have to follow a path of formal education. While I find Bandura's model of efficacy and self-efficacy ${ }^{4}$ more practical - particularly that they are distinctive and sometimes inversely related - it does raise the issue of hubris (hearkening back to Greek tragedy).

At the risk of demonstrating my level of movie-watching for the past few years (a hazard of having growing children in the house), the concept of intellectual humility reminded me of 
Ratatouille, a cute movie about the rat in Paris who becomes a chef. In the end, the food critic who has a reputation for raking chefs over the coals with scathing and career ending reviews has a reversal and acknowledges:

In the past, I have made no secret of my disdain for Chef Gusteau's famous motto: Anyone can cook. But I realize, only now do I truly understand what he meant. Not everyone can become a great artist, but a great artist can come from anywhere. It is difficult to imagine more humble origins than those of the genius now cooking at Gusteau's, who is, in this critic's opinion, nothing less than the finest chef in France. (Ratatouille)

As juvenile as it may seem, this demonstrates two important points - that genius or intellect is not limited to the standard or assumed path (which is also reinforced in Good Willing Hunting) and that in order to move forward and learn (and perhaps even be fulfilled), we all need to be cognizant of our mistakes and areas where we are either ignorant or wrong. The character Anton Ego experiences this in the movie and has the courage to admit when his assumptions (the assumptions that he built his career on) were wrong. This is not behavior that we commonly see (although I was pleasantly surprised to see it reported in the first week of the new Presidential Administration) - but it is to be pursued.

Oddly enough, I feel like librarians are in a conundrum - as information specialists, they are expected to know, to have the answers, and to be able to address any question or problem that comes at them. Thus, it seems there is a widespread hesitancy to admit a mistake or say, "I don't know." However, being able to admit that one makes mistakes or that one does not know is the only way in which one can learn.

Recently, I was working on a project that looked at how universities demonstrate their commitment to the public. The assumptions that we made about findings were, shockingly, not borne out. This also caused me to question the role and benefits of higher education (over other forms of education or training) since more and more it seems like college is only for the elite (or for those who can mortgage their futures through student loans). Between our exchange student and a colleague originally from Denmark, we were also educated about how other countries provide higher education for their citizens (countries that also have universal healthcare and tend to score higher on PISA, for what it is worth). It seems that higher education, in general, and some universities in particular could use a dose of intellectual humility too.

Thinking about serving as editor of a journal (as we are in the middle of a search for a new editor), I am remined about the role an editor plays and that, in my opinion, intellectual humility is a requirement. Editors, like librarians, are often looked at as the ultimate authority - that they have all the answers (or this may just be the pressure that we put on ourselves). However, in this continually-evolving environment, there is no way to have all the answers. I was also recently reminded that, while the responsibility ultimately belongs to the editors, there are many more people invested in the cause who bring their own expertise and commitment. I realize I should rely on my editorial board and staff more - that they are happy to engage and take on projects that move the journal forward, to address issues raised, or even to just help with logistics of board meetings. 
Intellectual humility also seems an appropriate lens with a lot of the sociopolitical movements we are seeing (Black Lives Matter, \#metoo, etc.), which have overturned a lot of assumptions that society had established about "the way things are." There are assumptions (and associated behavior) that should be overturned-and we need to do more than just acknowledge them - we need to apologize for them and do what we can to learn from them and do better.

I am struck as I re-read this March issue that often intellectual humility and courage go hand in hand. There are several articles in this issue that tackle assumptions and inequities that we, as a profession, can and should address (and in some cases, are addressing already). It takes humility to ask these questions - and courage to answer them. It is gratifying to see these studies come to publication and I am humbled by the authors' commitment and courage- and strive to emulate them.

\section{Notes}

1. BBC Reel, "The Importance of Knowing You Might Be Wrong," May 14, 2020, https:/www.bbc.co.uk/ideas/ videos/the-importance-of-knowing-you-might-be-wrong/p08d53s8.

2. Ibid.

3. Thomas Schlösser, David Dunning, Kerri L. Johnson, and Justin Kruger, “How unaware are the unskilled? Empirical tests of the 'signal extraction' counterexplanation for the Dunning-Kruger effect in self-evaluation of performance." Journal of Economic Psychology 39 (2013): 85-100, https://doi.org/10.1016/j.joep.2013.07.004.

4. Albert Bandura, Self-Efficacy: The Exercise of Control (London: Macmillan Publishers, 1997), 158-66. 